CLINICAL STUDY

\title{
Pilot study on the assessment of the setpoint of the hypothalamus-pituitary-thyroid axis in healthy volunteers
}

\author{
N Benhadi, E Fliers, T J Visser ${ }^{1}$, J B Reitsma ${ }^{2}$ and W M Wiersinga \\ Department of Endocrinology and Metabolism, Academic Medical Centre, University of Amsterdam, Meibergdreef 9, 1105 AZ Amsterdam, \\ The Netherlands, ${ }^{1}$ Department of Endocrinology, Erasmus Medical Centre, Erasmus University Rotterdam, 3015 GE Rotterdam, The Netherlands and \\ ${ }^{2}$ Department of Clinical Epidemiology and Biostatistics, Academic Medical Centre, University of Amsterdam, Meibergdreef 9, 1105 AZ Amsterdam, \\ The Netherlands
}

(Correspondence should be addressed to N Benhadi; Email: n.benhadi@amc.uva.nl)

\begin{abstract}
Objective: To determine the log-linear relationship between TSH and free thyroxine in healthy subjects, and the variation in baseline $\mathrm{TSH} /$ free thyroxine $\left(\mathrm{FT}_{4}\right)$ combination in each individual.

Subjects and methods: Twenty-one healthy volunteers (nine males and 12 females; mean age 60 years, range 51-74) were randomized to receive at $2300 \mathrm{~h}$ with 2-week intervals a single dose of placebo, $125 \mu \mathrm{g} \mathrm{T}_{4}$ and $250 \mu \mathrm{g} \mathrm{T}_{4}(\operatorname{arm~} 1, n=10)$, or placebo, $25 \mu \mathrm{g}$ triiodothyronine $\left(\mathrm{T}_{3}\right)$ and $50 \mu \mathrm{g} \mathrm{T}_{3}(\operatorname{arm}$ $2, n=11)$. Blood samples were taken in the morning $(0800-1100 \mathrm{~h})$ before and following the administration of the drug for the assessment of $\mathrm{TSH}, \mathrm{FT}_{4}$ and $\mathrm{T}_{3}$.

Results: Intra- and inter-individual variation and the individuality index of the four baseline serum samples were respectively $21.6 \%, 41.9 \%$ and 0.52 for $\mathrm{TSH} ; 9.9 \%, 16.5 \%$ and 0.60 for $\mathrm{FT}_{4}$; and $9.3 \%$, $16.0 \%$ and 0.58 for $\mathrm{T}_{3}$. Substantial differences existed in the location of individual working points within the reference range. $\mathrm{T}_{4}$ administration increased $\mathrm{FT}_{4}$ (but not $\mathrm{T}_{3}$ ) and decreased TSH, resulting in a $\log$-linear relationship $\left(\log \mathrm{TSH}=1.50-0.059 \times \mathrm{FT}_{4}, \quad P<0.05\right)$ for the whole group. $\mathrm{T}_{3}$ administration increased $\mathrm{T}_{3}$ and decreased TSH (but not $\mathrm{FT}_{4}$ ), resulting in a log-linear relationship $\left(\log \mathrm{TSH}=0.790-0.245 \times \mathrm{T}_{3}, P<0.001\right)$ for the whole group. Log-linear relationships were not always significant when assessed for each subject separately.

Conclusion: Individuality indices of $\mathrm{TSH}, \mathrm{FT}_{4}$ and $\mathrm{T}_{3}$ are all $\leq 0.6$, thereby limiting the usefulness of the population-based reference values. Accurate assessment of individual setpoints of the HPT axis was not possible with the applied single doses of $\mathrm{T}_{4}$ or $\mathrm{T}_{3}$, and will require either prolonged administration or higher single doses of thyroid hormone.
\end{abstract}

European Journal of Endocrinology 162 323-329

\section{Introduction}

Many studies report a log-linear relationship between serum TSH and free thyroxine $\left(\mathrm{FT}_{4}\right)$ over a wide concentration range $(1,2)$. This has been demonstrated in cross-sectional studies encompassing hyperthyroid, euthyroid and hypothyroid subjects (2), but also within individuals in longitudinal studies. When patients with primary hypothyroidism are treated with levo $\mathrm{T}_{4}\left(\mathrm{~L}-\mathrm{T}_{4}\right)$, the interrelated changes in serum $\mathrm{FT}_{4}$ and $\mathrm{TSH}$ move along a straight line (3). Conversely, when euthyroid subjects are treated with large doses of $\mathrm{T}_{4}$ to render them hyperthyroid, serum $\mathrm{FT}_{4}$ and $\mathrm{TSH}$ values also move along a straight line, but in the opposite direction (2). The straight line represents the setpoint of the hypothalamuspituitary-thyroid (HPT) axis (Fig. 1). The slope of the line is an indicator of the sensitivity of the HPT axis for changes in ambient thyroid hormone concentrations. Indeed in patients with thyroid hormone resistance, the slope is flattened (4). Only small variations in the slope have been observed between healthy individuals as evident from parallel straight lines representing individual setpoints (2), but studies on this subject are few. It is thus assumed that each individual has about the same slope for his/her $\log$-linear $\mathrm{TSH} / \mathrm{FT}_{4}$ relation, but intercepts vary.

There is a considerable variation in serum TSH and thyroid hormone concentrations in healthy subjects, in whom the inter-individual variability is much greater than the intra-individual variability (5-12). It looks like every individual has his/her own peculiar combination of TSH and $\mathrm{FT}_{4}$, which is determined by genetic and environmental factors (13). We like to refer to this specific $\mathrm{TSH} / \mathrm{FT}_{4}$ combination as the working point on the straight line depicting the log-linear $\mathrm{TSH} / \mathrm{FT}_{4}$ relationship which represents the setpoint of the HPT axis.

Determination of the working point and the setpoint of the HPT axis is of much theoretical interest, but it may also have clinical relevance (14). For instance, the distance along the setpoint line to reach supranormal TSH values (that is the decrease in serum $\mathrm{FT}_{4}$ ) is much greater when 


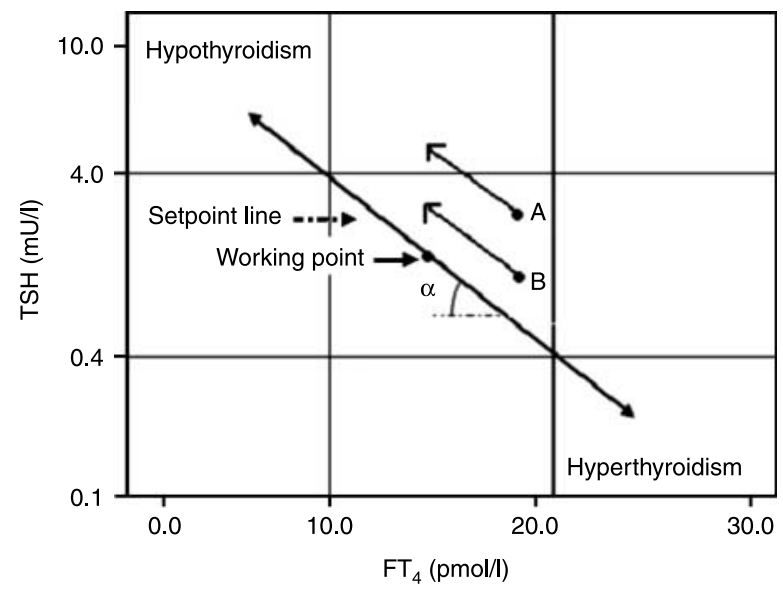

Figure 1 Log-linear relationship between serum $\mathrm{TSH}_{\text {and }} \mathrm{FT}_{4}$ depicted as a straight line, representing the setpoint of the hypothalamus-pituitary-thyroid axis. The slope $\alpha$ indicates the sensitivity of the HPT axis for changes in $\mathrm{FT}_{4}$. The working point at the line represents the actual thyroid state. The position of the working point of healthy euthyroid subjects varies greatly within the normal reference range (TSH 0.4-4.0 $\mathrm{mU} / \mathrm{l}$ and $\left.\mathrm{FT}_{4} 10-21 \mathrm{pmol} / \mathrm{l}\right)$.

This may have clinical relevance, e.g. subclinical hypothyroidism (TSH $>4.0 \mathrm{mU} / \mathrm{l}$ but normal $\mathrm{FT}_{4}$ ) will be diagnosed at an earlier time in subject $A$ than in subject $B$ despite an equal decrease in serum $\mathrm{FT}_{4}$.

the working point is located in the lower part of the reference area as compared to the upper part (Fig. 1). Up to now, very few studies have assessed individual setpoints of the HPT axis. The aim of the present study was to develop a feasible and practical method for assessing not only the individual working point but also the setpoint of the HPT axis in healthy subjects.

\section{Subjects and methods}

\section{Subjects}

We included healthy volunteers aged 50 years or older who were recruited by advertisements in local newspapers. Exclusion criteria were past or present thyroid disease, thyroid function tests outside the reference range, active cardiovascular disease, severe illness and thyroid-influencing medication or oestrogens. All subjects lived in the iodine-replete region of Amsterdam, The Netherlands. An electrocardiogram (ECG) was performed before inclusion to exclude patients with cardiac arrhythmias. This study was carried out with the approval of the local ethics committee of the Academic Medical Centre of the University of Amsterdam. All subjects gave written consent before entering the study.

\section{Study design}

Subjects were randomized in a 1:1 ratio to either the $T_{4}$ or triiodothyronine $\left(\mathrm{T}_{3}\right)$ intervention arm (Fig. 2). In each arm, oral medication was given three times: either placebo, $125 \mu \mathrm{g} \mathrm{T}_{4}$ and $250 \mu \mathrm{g} \mathrm{T}_{4}$ (arm 1), or placebo, $25 \mu \mathrm{g} \mathrm{T}_{3}$ and $50 \mu \mathrm{g} \mathrm{T}_{3}$ (arm 2). The subjects always started with placebo, followed as determined by a second randomization by the low dose or the high dose of $\mathrm{T}_{4}$ or $\mathrm{T}_{3}$. In both arms, there was a minimum 2 -week interval between the medication intakes (washout period). Subjects were instructed to take the medication at $2300 \mathrm{~h}$. A blood sample was collected in the morning (0800-1100 h) of the day before and in the morning of the day after the medication was taken. Pulse rate, blood pressure and body weight were measured during each visit. Subjects were blinded with regard to the prescribed drugs and doses.

\section{Assays}

Non-fasting venous blood samples were taken for thyroid hormone measurements and stored at $-20{ }^{\circ} \mathrm{C}$ until assay. Serum $\mathrm{T}_{3}$ was measured with in-house RIA. Serum $\mathrm{FT}_{4}$ was assayed by time-resolved fluoroimmunoassay (Delfia, Turku, Finland). Serum TSH was determined with a fluoroimmunometric assay

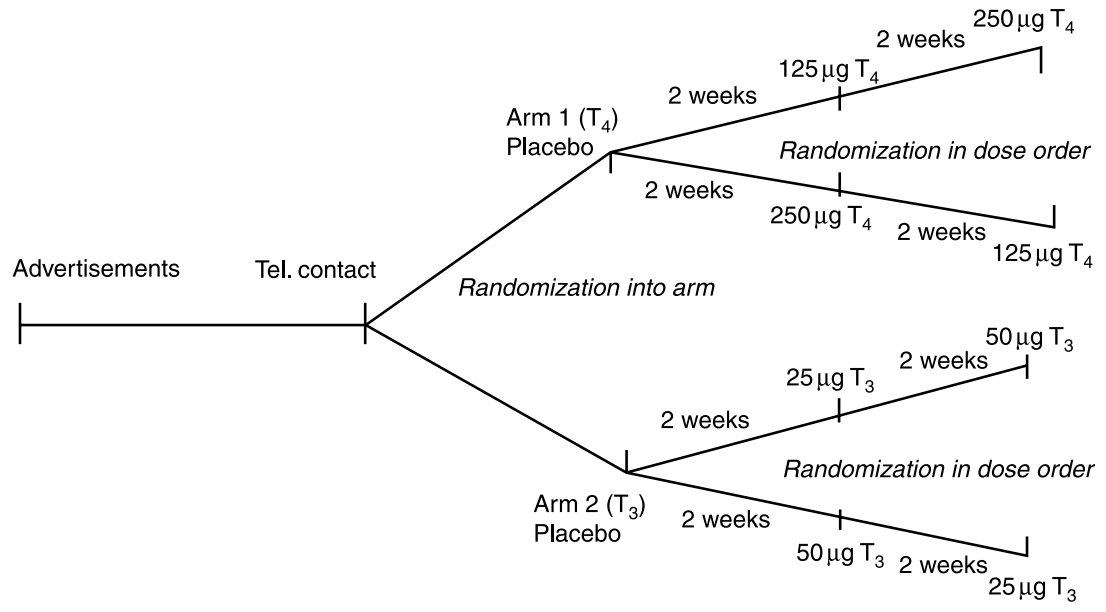

Figure 2 Study design. 
(Delfia hTSH, Perkin-Elmer, Turku, Finland). All samples of one individual were measured in the same assay run. Reference values are $0.4-4.0 \mathrm{mU} / \mathrm{l}$ for TSH, $10-21 \mathrm{pmol} / \mathrm{l}$ for $\mathrm{FT}_{4}$ and $1.30-2.70 \mathrm{nmol} / \mathrm{l}$ for $\mathrm{T}_{3}(15)$.

\section{Statistical analysis}

Serum $\mathrm{FT}_{4}$ values were normally distributed. TSH distribution was skewed, but it became normal after transformation (natural logarithm) evaluated by the Shapiro-Wilk test and normality plots. The intraindividual variance of baseline thyroid function tests (four measurements for each individual) was calculated by the variation for each individual, and the interindividual variance was calculated by the variation of individual means. The individuality index was the ratio of intra- to inter-individual variation (16). Calculations using ANOVA gave similar variances. Differences in thyroid function level tests within each arm were evaluated with the paired $t$-test. The log-linear relationship between $\operatorname{lnTSH}$ and $\mathrm{FT}_{4}$ or $\mathrm{T}_{3}$ was tested by mixed model analysis, exponential model analysis and linear regression analysis for the whole group as a total and for each intervention arm separately. A $P$ value of $<0.05$ was considered statistically significant. All statistical analyses were performed using the statistical package for social sciences version 15.0 (SPSS Inc., Chicago, IL, USA).

\section{Results}

We recruited 21 healthy subjects (9 males and 12 females) with an average age of 60 years (range 51-74); all except one were Caucasians. The average body mass index was 25.4 (range 18.4-31.1). All volunteers completed the study without complaints or side effects.

Figure 3 depicts the mean values \pm s.E.M. of individual baseline thyroid function tests derived from four separate blood samples, three taken the morning before the administration of the study drug and one taken the morning after the administration of placebo the previous evening. The intra-individual variation coefficients (mean and range) are 21.6\% (4.4-46.9) for TSH, 9.9\% (1.9-22.4) for $\mathrm{FT}_{4}$, and 9.3\% (0.0-22.1) for $\mathrm{T}_{3}$. Taking the mean value of each individual, the mean value \pm s.D. of the whole group of 21 healthy subjects are $1.86 \pm 0.78 \mathrm{mU} / \mathrm{l}$ for TSH, $14.83 \pm 2.45 \mathrm{pmol} / \mathrm{l}$ for $\mathrm{FT}_{4}$ and $1.81 \pm 0.29 \mathrm{nmol} / \mathrm{l}$ for $\mathrm{T}_{3}$. The mean group intra- and inter-individual variation is listed in Table 1. The within-individual differences of all three thyroid function tests are lower than the between-individual differences, resulting in an intra-individual to interindividual variation coefficient ratio $\leq 0.60$. The particular combination of each individual mean TSH and $\mathrm{FT}_{4}$ or mean $\mathrm{TSH}$ and $\mathrm{T}_{3}$ values reflects the actual working point of the HPT axis in that individual, which
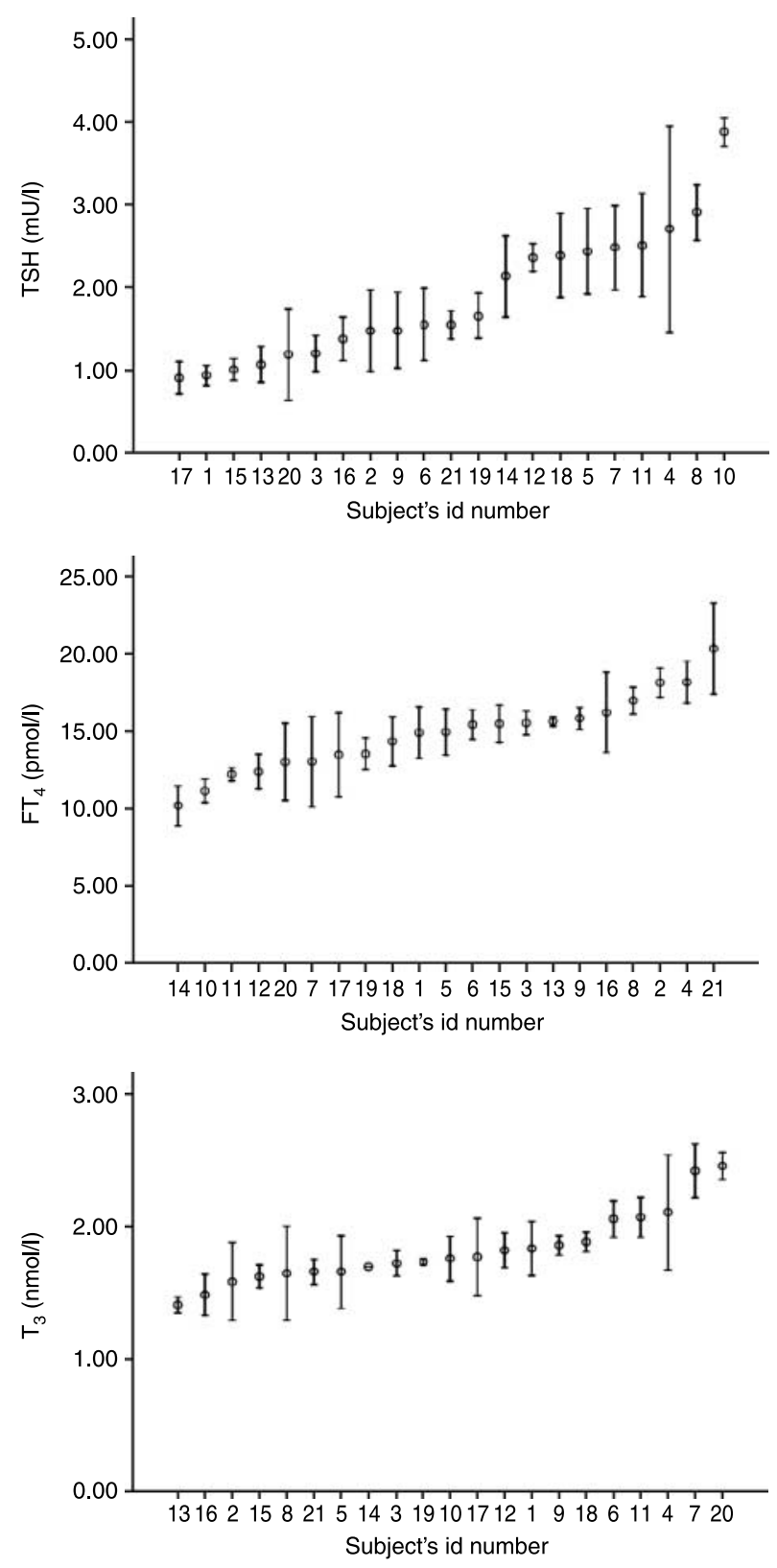

Figure 3 Mean values \pm S.E.M. of baseline serum TSH, $\mathrm{FT}_{4}$ and $\mathrm{T}_{3}$ concentrations in 21 healthy subjects, as calculated from four separate morning blood samples withdrawn over a 4-week period and ranked from lowest to highest mean value.

is graphically depicted in Fig. 4. Although all working points lie within the reference area, their location is widely scattered.

The results of thyroid function tests before and after the administration of $\mathrm{T}_{4}(\operatorname{arm} 1, n=10)$ or $\mathrm{T}_{3}(\operatorname{arm} 2$, $n=11$ ) are shown in Fig. 5 . In both intervention arms, the serum $\mathrm{TSH}, \mathrm{FT}_{4}$ and $\mathrm{T}_{3}$ levels were similar in the three blood samples withdrawn in the morning before the study drugs were taken. This indicates that the 2-week washout interval was sufficient. In treatment 
Table 1 Individuality indices of serum $\mathrm{TSH}, \mathrm{FT}_{4}$ and $\mathrm{T}_{3}$ in healthy subjects as reported in the literature.

\begin{tabular}{|c|c|c|c|c|c|c|}
\hline & $\begin{array}{l}2008 \text { Present } \\
\text { study }\end{array}$ & 2002 Ref. (5) & 1997 Ref. (6) & 1993 Ref. (7) & 1990 Ref. (9) & 1986 Ref. (10) \\
\hline \multicolumn{7}{|l|}{ Study characteristics } \\
\hline Number of subjects & 21 & 15 & 26 & 47 & 15 & 12 \\
\hline Number of samples per subject & 4 & 12 & 12 & 5 & 7 & 7 \\
\hline Sampling period, weeks & 4 & 52 & 52 & 2 & 1 & 5 \\
\hline \multicolumn{7}{|l|}{ TSH variation } \\
\hline Intra-individual variation, \% & 21.6 & 22.4 & 29.3 & 29.0 & 19.3 & 16.2 \\
\hline Inter-individual variation, \% & 41.9 & 43.9 & 48.4 & 80.5 & 19.7 & 31.7 \\
\hline Individuality index ${ }^{\mathrm{a}}$ & 0.52 & 0.51 & 0.60 & 0.36 & 0.98 & 0.50 \\
\hline \multicolumn{7}{|l|}{$\mathrm{FT}_{4}$ variation } \\
\hline Intra-individual variation, \% & 9.9 & $10.7^{\mathrm{b}}$ & 7.1 & 12.2 & - & 9.5 \\
\hline Inter-individual variation, \% & 16.5 & $20.3^{b}$ & 9.1 & 20.3 & - & 12.3 \\
\hline Individuality index ${ }^{\mathrm{a}}$ & 0.60 & 0.53 & 0.78 & 0.60 & - & 0.78 \\
\hline \multicolumn{7}{|l|}{$\mathrm{T}_{3}$ variation } \\
\hline Intra-individual variation, \% & 9.3 & 12.0 & 9.4 & 11.4 & 8.7 & 10.4 \\
\hline Inter-individual variation, \% & 16.0 & 20.4 & 18.5 & 21.5 & 18.0 & 20.4 \\
\hline Individuality index ${ }^{\mathrm{a}}$ & 0.58 & 0.59 & 0.51 & 0.53 & 0.48 & 0.51 \\
\hline
\end{tabular}

andividuality index $=$ ratio of intra- to inter-individual variation.

${ }^{\mathrm{b}} \mathrm{FT}_{4}$ index.

arm 1, serum $\mathrm{FT}_{4}$ increased (significantly) and $\mathrm{TSH}$ decreased (not significantly) after $\mathrm{T}_{4}$ administration, but $\mathrm{T}_{3}$ remained unchanged (Fig. 5). There existed a significant log-linear relationship between $\mathrm{TSH}$ and $\mathrm{FT}_{4}$ in this group as a whole $\left(\log \mathrm{TSH}=1.50-0.059 \times \mathrm{FT}_{4}\right.$, $P$ for slope $<0.05$; Fig. $6 \mathrm{~A}$ ), but the relationship was not always significant if evaluated in each individual separately. In treatment arm 2 , serum $\mathrm{T}_{3}$ increased and TSH decreased after $\mathrm{T}_{3}$ administration, but $\mathrm{FT}_{4}$ remained unchanged. A significant log-linear relationship between TSH and $\mathrm{T}_{3}$ was observed in this group as a whole $\left(\log \mathrm{TSH}=0.790-0.245 \times \mathrm{T}_{3}, P\right.$ for slope $<0.001$; Fig. 6B), but not in every individual subject.

\section{Discussion}

The first finding of our study is that the working point of the HPT axis in a particular individual can be determined reasonably well from four separate morning blood samples withdrawn over a 4-week period. The intra- and inter-individual variation coefficients and the individuality index of $\mathrm{TSH} \mathrm{FT}_{4}$ and $\mathrm{T}_{3}$ in our study are in close agreement with those observed in other studies in which 12 samples were collected over a 52-week period (Table 1). Only one study reports much higher individuality indices (9), which is likely explained by a very short sampling period of 1 week. The data further suggest a very limited effect of seasonal variation in thyroid function tests on the working point of the HPT axis (14). Estimation of an individual's working point becomes more precise by full standardization of the conditions under which blood samples are drawn. In this respect, the intra-individual variation observed in the present study could have been narrower by sampling at more precisely the same hour in the morning, thereby avoiding the circadian variation (especially in TSH) occurring in the presently allowed sampling period of $3 \mathrm{~h}$ between 0800 and $1100 \mathrm{~h}$.
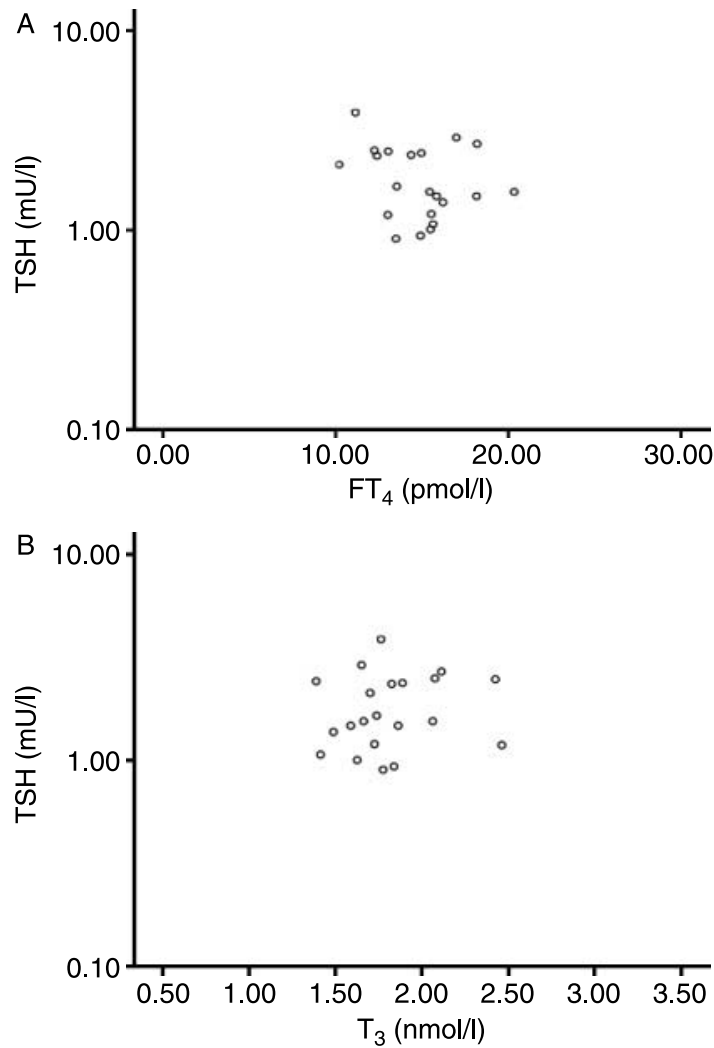

Figure 4 Individual TSH/ $\mathrm{FT}_{4}$ (panel A) and $\mathrm{TSH} / \mathrm{T}_{3}$ (panel B) combinations representing the actual working point of the HPT axis in 21 healthy subjects. Horizontal and vertical lines indicate clinical reference intervals of $\mathrm{TSH}$ and $\mathrm{FT}_{4} / \mathrm{T}_{3}$ respectively. 

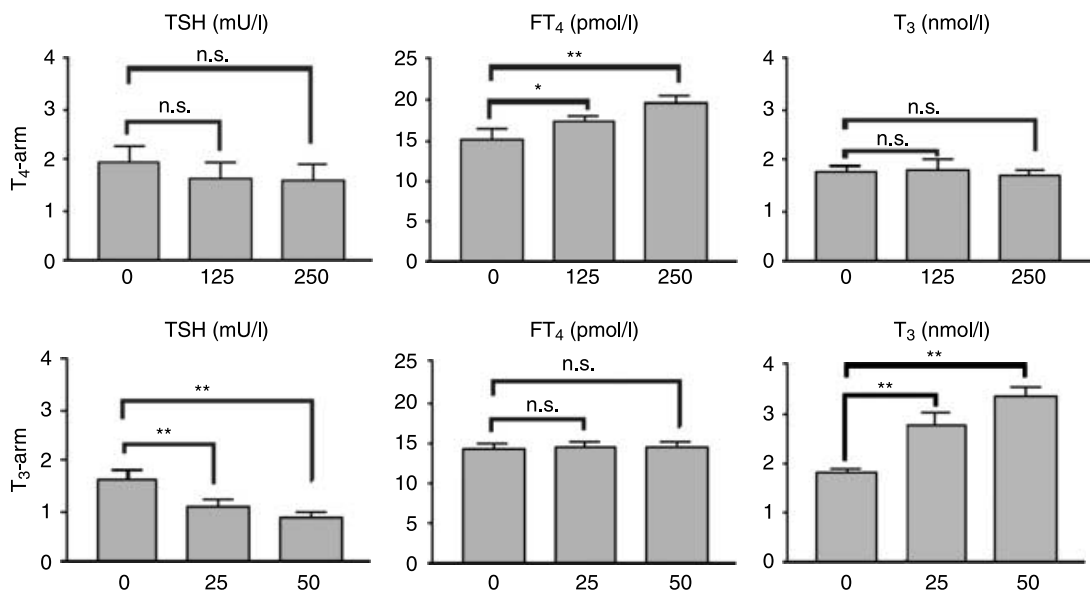

Figure 5 The mean ( \pm s.D.) $\mathrm{TSH}, \mathrm{FT}_{4}$ and $\mathrm{T}_{3}$ concentrations in each intervention arm before and after oral supplementation of placebo, $\mathrm{T}_{4}(125$ and $250 \mu \mathrm{g})$ or $\mathrm{T}_{3}(25$ and $50 \mu \mathrm{g})$. ${ }^{\star} P<0.05 ;{ }^{* \star} P<0.001 ;{ }^{\circledR} \mathrm{T}_{4}$-arm represents the treatment arm 1 and $\mathrm{T}_{3}$-arm represents the treatment arm 2.

Our second finding is that substantial differences exist between individuals in the location of their working point of the HPT axis within the reference area (Fig. 4), limiting the usefulness of population-based reference ranges in the identification of disease in an individual as noted before (5). When the individuality index is $<0.6$, the population-based reference range is an insensitive measure in the large majority of individuals; when the index is $>1.4$, the reference range works as intended (16). The individuality indices of $\mathrm{TSH}, \mathrm{FT}_{4}$ and $\mathrm{T}_{3}$ are mostly below 0.6 and below 1.0 in all the studies published so far (Table 1). Consequently, values within the population-based references ranges do not necessarily indicate a normal thyroid function in that individual.

As a third finding, the present study suggests that the setpoint of the HPT axis can be determined from the $\mathrm{TSH} / \mathrm{FT}_{4}$ response to the separate administration of three single doses of oral $\mathrm{T}_{4}(0,125$ and $250 \mu \mathrm{g}$ respectively), at least at a group level. Assessment of the setpoint per individual was less reliable in the present setting because the individual log-linear relationship was not significant in all subjects.

Possible explanations for the failure to establish individual setpoints of the HPT axis in our study are i) differences in intestinal absorption of the administered $\mathrm{L}^{-} \mathrm{T}_{4}$ between individuals, ii) too low doses of the administered $\mathrm{L}-\mathrm{T}_{4}$, and iii) differences in particular genotypes affecting the ambient $\mathrm{TSH}$ and $\mathrm{FT}_{4}$ levels between individuals. The latter possibility would indicate real differences in the setpoint of the HPT axis between our subjects. Indeed ethnic differences in ambient TSH values but not in $\mathrm{FT}_{4}$ values suggest an effect of race $(17,18)$, and slightly lower TSH values have been observed in carriers of the Asp727Glu polymorphism in the TSH receptor gene occurring in about $20 \%$ of a Caucasian population (19). The low prevalence of this TSH receptor polymorphism does not favour possibility iii) in our (mostly Caucasian) subjects. Possibility i) also is an unlikely explanation because the $\mathrm{TSH} / \mathrm{FT}_{4}$ relationship is determined by their interdependent serum concentrations, irrespective of the extent of intestinal $\mathrm{T}_{4}$ absorption. Therefore, we consider a too low dose of administered $\mathrm{T}_{4}$ as the most
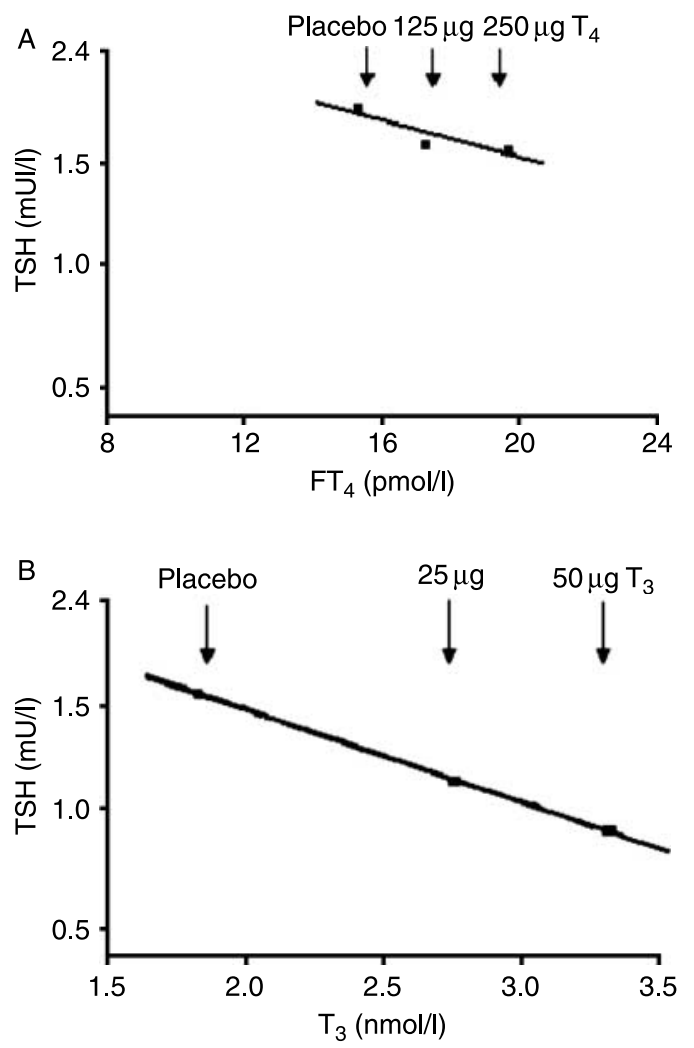

Figure 6 Log-linear relationship between $\mathrm{TSH}$ and $\mathrm{FT}_{4} / \mathrm{T}_{3}$ in 10 healthy subjects treated with oral $\mathrm{T}_{4}$ (panel $\mathrm{A}$ ) and in 11 healthy subjects treated with oral $T_{3}$ (panel $B$ ). 
likely explanation for our failure to determine the setpoint of the HPT axis in each individual separately. Supporting this view is the absence of a difference in TSH and $\mathrm{T}_{4}$ at individual values before and after receiving $125 \mu \mathrm{g} \mathrm{T}_{4}$. Only within a group $\left(\mathrm{T}_{4}\right.$-arm), there was a significant increase in the measured $\mathrm{FT}_{4}$ not in the $\mathrm{TSH}$ and $\mathrm{T}_{3}$ (Fig. 5). The relatively small differences in $\mathrm{TSH}$ and $\mathrm{FT}_{4}$ values after ingestion of 125 or $250 \mu \mathrm{g} \mathrm{T}_{4}$ might be related to the increase of $\mathrm{L}_{-} \mathrm{T}_{4}$ metabolic clearance rate when the $\mathrm{L}_{-} \mathrm{T}_{4}$ dose exceeds $2.0 \mu \mathrm{g} / \mathrm{kg}$ per day (3). We conclude from our pilot study that prolonged administration of $\mathrm{L}^{-\mathrm{T}_{4}}$ or higher single doses of $\mathrm{T}_{4}$ (e.g. 250 and $500 \mu \mathrm{g}$ ) are required to determine accurately one's individual setpoint of the HPT axis.

Nevertheless, the log-linear $\mathrm{TSH} / \mathrm{FT}_{4}$ relationship was significant when the ten subjects in the $\mathrm{T}_{4}$ intervention arm were considered together: $\log \mathrm{TSH}=1.50-0.059$ $\times \mathrm{FT}_{4}, P<0.05$. Extrapolating this relationship, TSH will be $32 \mathrm{mU} / \mathrm{l}$ at a $\mathrm{FT}_{4}$ of $0 \mathrm{pmol} / \mathrm{l}$, and $\mathrm{FT}_{4}$ will be $59.3 \mathrm{pmol} / \mathrm{l}$ at a given TSH value of $0.01 \mathrm{mU} / \mathrm{l}$. The data can be compared with those of Spencer et al. (2) who reported the following log-linear $\mathrm{TSH} / \mathrm{FT}_{4}$ relationship in 505 stable ambulatory patients who were either hypothyroid, euthyroid or hyperthyroid: log $\mathrm{TSH}=2.56-0.022 \times \mathrm{FT}_{4}$ index, $r=-0.84, P<0.001$. In this formula, TSH will be $360 \mathrm{mU} / \mathrm{l}$ at a $\mathrm{FT}_{4}$ index of 0 , and $\mathrm{FT}_{4}$ index is 207 at a given TSH value of $0.01 \mathrm{mU} / \mathrm{l}$. From clinical practice, it is evident that undetectable $\mathrm{FT}_{4}$ values are associated with much higher TSH values than $32 \mathrm{mU} / \mathrm{l}$. Consequently, our study underestimates the slope of the setpoint of the HPT axis, which is most likely caused by too low doses of administered $\mathrm{T}_{4}$.

We encountered similar problems in the $\mathrm{T}_{3}$ intervention arm. Although the log-linear relationship between TSH and $\mathrm{T}_{3}$ was significant for all 11 subjects together, this was not true for each individual. We selected the doses of 25 and $50 \mu \mathrm{g} \mathrm{T}_{3}$ in view of the biological potency ratio of 5:1 for $\mathrm{T}_{4}$ and $\mathrm{T}_{3}$ on a weight basis (20). It would be of much interest to see whether the sensitivity of the pituitary to suppress TSH is similar for equivalent doses of exogenous $\mathrm{T}_{4}$ and $\mathrm{T}_{3}$. In the study of Fish et al. (3), suppression of pituitary TSH secretion was more clearly related to serum $\mathrm{T}_{3}$ than to serum $\mathrm{T}_{4}$, whereas Silva et al. (21) and Larsen (22) proposed that $\mathrm{T}_{4}$ rather than $\mathrm{T}_{3}$ has a dominant role in regulating pituitary $\mathrm{TSH}$ secretion in view of active conversion of $\mathrm{T}_{4}$ into $\mathrm{T}_{3}$ within the pituitary accounting for about $50 \%$ of nuclear $\mathrm{T}_{3}$ in the pituitary. Burmeister et al. reported that the relationship between free $\mathrm{T}_{3}$ index and TSH in stable hypothyroid patients on $\mathrm{L}^{-\mathrm{T}_{4}}$ treatment is similar to that between $\mathrm{TSH}$ and $\mathrm{FT}_{4}$ index (23). The most appropriate study design in this respect would be the administration of various doses of $\mathrm{T}_{4}$ and $\mathrm{T}_{3}$ to the same subjects.

In summary, four separate blood samples taken over a 4-week period allow for a reasonable estimate of an individual's working point at the HPT axis. Substantial differences between individuals in the location of their working point within the reference area limit the usefulness of the population-based reference ranges. Accurate assessment of the log-linear relationship between $\mathrm{TSH}$ and $\mathrm{FT}_{4}$ (the setpoint of the HPT axis) was not possible by the administration of single doses of $\mathrm{T}_{4}(125-250 \mu \mathrm{g})$ or $\mathrm{T}_{3}(25-50 \mu \mathrm{g})$, but it requires either prolonged administration or higher single doses of thyroid hormones.

\section{Declaration of interest}

The authors declare that there is no conflict of interest that could be perceived as prejudicing the impartiality of the research reported.

\section{Funding}

This study was financially supported by a grant from ZonMW (94800007).

\section{References}

1 Wehmann RE \& Nisula BC. Radioimmunoassay of thyrotropin: analytic and clinical developments. Critical Reviews in Clinical Laboratory Sciences 198420 243-283.

2 Spencer CA, LoPresti JS, Patel A, Guttler RB, Eigen A, Shen D, Gray D \& Nicoloff JT. Applications of a new chemiluminometric thyrotropin assay to subnormal measurement. Journal of Clinical Endocrinology and Metabolism 1990 70 453-460.

3 Fish LH, Schwartz HL, Cavanaugh J, Steffes MW, Bantle JP \& Oppenheimer JH. Replacement dose, metabolism, and bioavailability of levothyroxine in the treatment of hypothyroidism. Role of triiodothyronine in the pituitary feedback. New England Journal of Medicine $1987316764-770$.

4 Ercan-Fang S, Schwartz HL, Mariash CN \& Oppenheimer JH. Quantitative assessment of pituitary resistance to thyroid hormone from plots of the logarithm of thyrotropin versus serum free thyroxine index. Journal of Clinical Endocrinology and Metabolism 200085 2299-2303.

5 Andersen S, Pedersen KM, Bruun NH \& Laurberg P. Narrow individual variations in serum $\mathrm{T}_{4}$ and $\mathrm{T}_{3}$ in normal subjects: a clue to the understanding of subclinical thyroid disease. Journal of Clinical Endocrinology and Metabolism 200287 1068-1072.

6 Maes M, Mommen K, Hendrickx D, Peeters R, D'Hondt P, Ranjan R, De Meyer F \& Scharpe S. Components of biologic variation, including seasonality, in blood concentrations of TSH, $\mathrm{TT}_{3}, \mathrm{FT}_{4}, \mathrm{PRL}$, cortisol and testosterone in healthy volunteers. Clinical Endocrinology 199746 587-598.

7 Nagayama I, Yamamoto K, Saito K, Kuzuya T \& Sato T. Subjectbased reference values in thyroid function tests. Endocrine Journal 199340 557-562.

8 Meier CA, Maisey MW, Lowry A, Muller J \& Smith MA. Interindividual differences in the pituitary-thyroid axis influence the interpretation of thyroid function tests. Clinical Endocrinology 1993 39 101-107.

9 Ricos C \& Arbos MA. Quality goals for hormone testing. Annals of Clinical Biochemistry 199027 353-358.

10 Browning MCK, Ford RP, Callaghan SJ \& Fraser CG. Intra- and inter-individual biological variation of five analytes used in assessing thyroid function: implications for necessary standards of performance and the interpretation of results. Clinical Chemistry $198632962-966$. 
11 Harrop JS, Ashwell K \& Hopton MR. Circannual and withinindividual variation of thyroid function tests in normal subjects. Annals of Clinical Biochemistry 198522 371-375.

12 Costongs GM, Janson PC, Bas BM, Hermans J, van Wersch JW \& Brombacher PJ. Short-term and long-term intra-individual variations and critical differences of clinical chemical laboratory parameters. Journal of Clinical Chemistry and Clinical Biochemistry $1985237-16$.

13 Hansen PS, Brix TH, Sorensen TI, Kyvik KO \& Hegedus L. Major genetic influence on the regulation of the pituitary-thyroid axis: a study of healthy Danish twins. Journal of Clinical Endocrinology and Metabolism 200489 1181-1187.

14 Andersen S, Bruun NH, Pedersen KM \& Laurberg P. Biologic variation is important for interpretation of thyroid function tests. Thyroid 200313 1069-1078.

15 Strieder TGA, Prummel MF, Tijssen JGP, Endert E \& Wiersinga WM. Risk factors for and prevalence of thyroid disorders in a cross-sectional study among healthy female relatives of patients with autoimmune thyroid disease. Clinical Endocrinology 200359 396-401.

16 Harris EK. Effects of intra- and interindividual variation on the appropriate use of normal ranges. Clinical Chemistry $1974 \mathbf{2 0}$ 1535-1542.

17 Price A, Obel O, Cresswell J, Catch I, Rutter S, Barik S, Heller SR \& Weetman AP. Comparison of thyroid function in pregnant and non-pregnant Asian and western Caucasian women. Clinica Chimica Acta 2001308 91-98.

18 Benhadi N, Wiersinga WM, Reitsma JB, Vrijkotte TGM, van der Wal MF \& Bonsel GJ. Ethnic differences in TSH but not in free $\mathrm{T}_{4}$ concentrations or TPO antibodies during pregnancy. Clinical Endocrinology $2007 \mathbf{6 6} 765-770$.

19 Peeters RP, van Toor H, Klootwijk W, de Rijke YB, Kuiper GG, Uitterlinden AG \& Visser TJ. Polymorphisms in thyroid hormone pathway genes are associated with plasma TSH and iodothyronine levels in healthy subjects. Journal of Clinical Endocrinology and Metabolism $2003 \mathbf{8 8} 2880-2888$.

20 Cody V. Thyroid hormone structure-function relationships. In The Thyroid: A Fundamental and Clinical Text, edn 9, pp 151-157. Eds LE Braverman \& RD Utiger, Philadelphia: Lippincott, Williams \& Wilkins, 2005.

21 Silva JE, Dick TE \& Larsen PR. The contribution of local tissue thyroxine monodeiodination to the nuclear 3,5,3'-triiodothyronine in pituitary, liver and kidney of euthyroid rats. Endocrinology $1978 \mathbf{1 0 3} 1196-1207$.

22 Larsen PR. Thyroid-pituitary interaction: feedback regulation of thyrotropin secretion by thyroid hormones. New England Journal of Medicine 1982306 23-32.

23 Burmeister LA, Goumaz MO, Mariash CN \& Oppenheimer JH. Levothyroxine dose requirements for thyrotropin suppression in the treatment of differentiated thyroid cancer. Journal of Clinical Endocrinology and Metabolism 199275 344-350.

Received 13 November 2009

Accepted 13 November 2009 